\title{
Investigating Writing Performance and Institutional Supports Among Teacher Candidates Who Transferred From Community Colleges
}

\author{
Katharine Pace Miles, ${ }^{* a}$ Leslie Craigo, ${ }^{\mathrm{b}}$ and Selenid Gonzalez-Freyc \\ aBrooklyn College/New York, United States

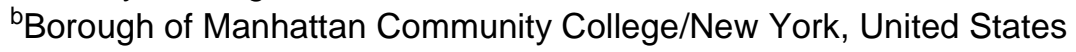 \\ 'The Graduate Center, City University of New York/New York, United States
}

Submitted: September 10, 2018 | Peer reviewed: December 13, 2018 | Accepted: December 24, 2018 |

Published: December 26, 2018

\begin{abstract}
To provide a snapshot of the skills of community college students as compared to senior college students in the United States, this exploratory study investigated the writing performance and college experience of initial 2-year enrolled (community college transfer students, $n=17$ ) versus initial 4-year enrolled students $(n=12)$ in a teacher preparation program. Results of independent samples t-tests on in-class writing, research paper, and final score were non-significant $(p=.28$, $p=.54, p=.15$, respectively) indicating that 2-year and 4-year start teacher candidates did not differ in their performance on these assignments nor overall in the course. Qualitative data indicated that while both 2- and 4-year start teacher candidates had a positive writing identity during their first 2 years of college, the personal support that 2-year starts had may have enabled them to succeed and have a positive writing identity once they transferred to a 4-year college. Implications regarding how to coordinate supports for transfer student teacher candidates will be discussed, as this is the very population of diverse students needed as PreK-12 teachers.
\end{abstract}

Keywords: preservice teachers, community college students, literacy

\section{Introduction}

Examining academic preparedness of community college students for transition to 4-year colleges is important in order to best support these students (Bailey \& Cho, 2010; Doyle, 2009). Research demonstrating that community college students sometimes experience negative attitudes from professors and staff at 4-year colleges compounds issues of academic preparedness (Eggleston \& Laanan, 2001), and students face challenges with curricular alignment and successful transfer of credits from one institution to another (Kopko \& Crosta, 2016; Lederman, 2017). This study examined academic performance and experience in a teacher preparation program with literacy heavy certification requirements. Furthermore, this project advocates for preservice teachers who come from underserved populations, a group included in community college populations.

The benefits of a 4-year college degree are well documented: increased income, expanded employment opportunities, upward social mobility, improved health, and an educated citizenry (Peralta, 2014; Oreopoulos \& Petronijevic, 2013; James, 2012). A 4-year degree is also the minimum required for many professions, including teaching elementary school. The pathway to a 4-year degree is varied. Some students start at a 2-year community college and then transfer to a 4-year college. Other students begin their college experience at a 4-year institution. Students

*Author correspondence: katiepacemiles@gmail.com

Suggested Citation: Miles, K. P., Craigo, L., \& Gonzalez-Frey, S. (2018). Investigating writing performance and institutional supports among teacher candidates who transferred from community colleges. Higher Learning Research Communications, 8(2), 35-54. http://dx.doi.org/10.18870/hlrc.v8i2.427 
may also come to college from high school with college courses or may take time off before beginning their college experience. While there are many paths, this paper examined a snapshot (Holiday et al., 2015) of the achievement of teacher candidates who start at a community college and transfer to a 4-year college as compared to teacher candidates who start at a 4-year school. The rationale for this study is based on notions that students from community college may not be as well prepared to complete higher-level college coursework as students who start at 4-year schools (Eggleston \& Laanan, 2001). Nowhere is there a greater need to examine preparedness than in teacher education, especially in light of the high stakes certification exams required of these students in order to receive their teaching license.

\section{Overview of Community Colleges}

In the United States, the historical higher education system started as 4-year institutions that served to educate clergy. This was expanded to include education for many other professions, including providing master's and doctoral programs. In the early 20th century, community colleges emerged to create a workforce and to serve as a place to prepare students to transfer to 4-year colleges and universities. These community colleges were often referred to as junior colleges and served as either training for a specific trade or as a bridge to 4-year colleges and universities.

When the first community college opened in 1901, its central mission was transfer; students would begin their education at a junior college and then transfer to a 4-year college or university (Townsend, 2001). An additional mission was to serve the needs of the local community by providing training and education close to home that would prepare a local workforce. Those students who were deemed in need of education beyond high school but not necessarily intellectually gifted enough for university work were trained for technical industry jobs or as elementary school teachers for local communities. Due to the success of this first community college, other localities and private institutions began developing junior and/or community colleges. Most were small, enrolling 150 students or less. Class sizes were small, allowing for individualized attention and abundant student-faculty interactions. Many of the early community colleges also provided extra-curricular activities (Dougherty \& Townsend, 2006; American Association of Community Colleges, 2016).

The first community colleges provided access and equity for those who would not have traditionally attended university: women, immigrants, the poor, and those seeking job training. As community colleges evolved, enrollment grew, the number of community colleges increased, and the mission expanded. Over the past 115 years, community colleges in the United States have become a point of access to higher education. Currently, almost half of students enrolled in higher education attend a community college (American Association of Community Colleges, 2016). First-generation college students, minorities, and students needing remedial help look to community colleges to provide job training and for transfer to 4-year colleges and universities (Dougherty \& Townsend, 2006).

Today community colleges in the United States are viewed as places that can increase low-income, academically underprepared students' chances of graduation (Perin \& Charron, 2006). While most colleges offer remedial courses and tutoring in basic reading, writing, and math, the major challenge for community colleges is setting the high standards needed for entry into 4year, college-level courses required for degree attainment.

As some 4-year institutions experience a crunch for space and become more expensive, community colleges provide a place for students to begin their higher education in an affordable 
and supported environment (Shannon \& Smith, 2006). As other 4-year institutions experience decreases in enrollment, they look to community colleges as a pipeline for students. However, with U.S. graduation and transfer rates for community college students ranging from $21 \%$ to $43 \%$, it could be argued that community colleges are not adequately fulfilling their mission of job-training and access to senior colleges and universities (Association of Community Colleges, 2016). For those students who do graduate, the question often is: Do community colleges adequately prepare students for transition to 4-year colleges?

\section{Comparison of Institutional Support}

The move from high school to college is a vast transition in terms of the work and level of thinking required, and many students require additional support to succeed. In the United States, $20 \%$ of first-year students in 4-year institutions and $42 \%$ of first-year students in 2 -year institutions enroll in remedial courses (Parsad \& Lewis, 2003). The general purpose of these remedial courses is to help underprepared students become equipped to succeed in their chosen field of higher education (Perin \& Charron, 2006). Although it is often of interest, there is a dearth of research that compares the efficacy of supports available at 4-year and 2-year institutions on students' postsecondary education success. Further, in the research that is available, there are differing findings regarding the efficacy of these supports at each type of institution (Adelman, 1998; Bettinger \& Long, 2004, 2005; Callahan \& Chumney, 2009; Parsad \& Lewis, 2003).

A longitudinal study comparing the efficacy of remedial courses for students enrolled in 4year and 2-year institutions found that the number of remedial courses in which students enrolled negatively affected their graduation (Adelman, 1998). However, remedial courses and support was less of a hindrance to degree attainment at 2-year compared to 4-year institutions. Contrary to these findings, Bettinger and Long examined the effectiveness of math and English remediation programs in 4-year (2004) and 2-year institutions (2005). In 4-year institutions, completion of remediation course work was linked to lower drop rates compared to students with similar abilities but not placed in remediation (Bettinger \& Long, 2004). For 2-year institutions, remediation had no discernible influence on students' persistence, measured based on likelihood of ceasing attendance (Bettinger \& Long, 2005). While these studies highlight the differential impact of remediation, questions remain regarding the causes of these differences as well as other supports offered by the institutions.

Callahan and Chumney (2009) examined differences in institutional resources and provisions of course content, instruction, and tutoring for remedial students in 4-year and community colleges. In terms of course content and instruction, the objective of the remedial course at the community college was to emphasize grammar and its proper usage in writing. The purpose was not to teach students to critically analyze text, but rather to improve deficiencies in students' knowledge. Using self-reports and interviews, students at the 2-year institution viewed their remedial work as helpful for their next remedial course in writing composition, but did not view it as helpful for other courses (Callahan \& Chumney, 2009).

Alternatively, the objective of the remedial course at the 4-year institution was to help students become analytic writers and to compose original arguments (Callahan and Chumney, 2009). Thus, Callahan and Chumney (2009) concluded that instructors at community colleges and 4-year institutions valued different writing competencies.

In addition, Callahan and Chumney (2009) found that tutoring was a main component in helping students with writing at a community college and 4-year institution. Both institutions provided out-of-class support for students; however, there was a notable disparity in the quantity 
and quality of the tutoring resources. In comparison to the community college, the 4-year institution had multiple layers of tutoring and support for students including providing a writing tutor for each remedial section offered to students. This tutor assisted students with brainstorming, draft writing, revising, and editing of papers as well as explaining difficult readings. The differences observed by Callahan and Chumney (2009) do not represent all community colleges or 4-year institutions, but rather shed light on the need to examine the type of resources that institutions provide to students engaging in remedial work as well as how those resources are received and perceived by students.

\section{Self-Efficacy and Writing}

Many community college students lack the literacy skills needed to succeed in college and careers (Perin, 2013), and, therefore, community colleges offer students remedial courses so they can gain the requisite skills to succeed in college. The number of students at community colleges taking remedial courses can be quite high. The U.S. average of students needing remediation is $38 \%$ in reading and $44 \%$ in writing (Perin, 2002). Students need to take these remedial courses because they have not passed the initial assessments necessary to take college-level courses.

Interestingly, research has shown that students' self-efficacy is connected to academic adjustment and decisions to persevere in college (Callahan \& Chumney, 2009). Gains in selfconfidence and writing self-efficacy are related to students' access to resources, which enable them to gain competence as college writers (Callahan \& Chumney, 2009; Pajares, 2003; Williams \& Takaku, 2011). The role of self-beliefs in academic attainment is consistent with Bandura's (1986) socio-cognitive perspective in which individuals are considered proactive and selfregulating agents. In this view, individuals possess beliefs about their capabilities that enable them a measure of control over their thoughts and actions.

The focus on students' self-beliefs as a core component of academic motivation is built on the notion that the beliefs that students develop and embrace to be true about themselves are fundamental forces in their academic success or failure (Pajares, 2003; Williams \& Takaku, 2011). Students' self-efficacy beliefs inform their identity as writers. Pajares (2003) examined the influence of self-efficacy on the writing tasks that take place in academic settings. The findings showed that students' confidence in their writing capabilities influenced their writing motivation as well as their writing outcomes in school.

Williams and Takaku (2011) analyzed the effect of writing self-efficacy and help-seeking behavior on writing performance as measured by final grades. Contrary to their initial hypothesis, that students with high self-efficacy would engage in high help-seeking behavior and students with low self-efficacy would be more reluctant to seek help, Williams and Takaku (2011) found an inverse relationship between self-efficacy and help-seeking behavior. Students with low writing self-efficacy frequented the writing center more. This was especially true for the English language learners in the study. Further, the researchers demonstrated that high levels of help-seeking behavior resulted in better performance in writing intensive classes.

Academic success requires that students adopt an active, rather than passive, role in their learning. It also requires that students have an understanding of the aptitude necessary to succeed at specific academic levels (Schunk \& Zimmerman, 1998). Williams and Takau's (2011) hypothesis about self-efficacy and help seeking could be informed by Schunk and Zimmerman's understanding of self-efficacy as self-knowledge of skills. Therefore, students who know that they are challenged by writing would seek help. One field where academic writing skills are coming under increased scrutiny is teacher training. The present study used a questionnaire to examine 
the self-efficacy writing beliefs and help-seeking behaviors of college students as a function of point of entry to college at either a 2-year community college or a 4-year university in the United States.

\section{Literacy Preparedness and Future Teachers}

Gambell (1991) studied elementary education preservice teachers' self-perceptions towards their writing as well as their process of academic writing. The findings indicated that students, regardless of being strong, successful writers, generally felt "frustrated" (Gambell, 1991, p. 421) and apprehensive with their own university-level writing. Students cited relying on the ideas and language of experts and suspending their own critical judgment when writing. They identified conceptualizing an audience as a difficulty when writing. Notably, preservice teachers' self-perceived writing difficulties focused on the rhetorical aspects of writing rather than on grammatical aspects. This finding is particularly useful for conceiving of the supports that students need to enhance their writing skills and self-efficacy. Students saw themselves as "apprentice writers and readers of discipline-specific language" (Gambell, 1991, p. 431) while they saw their professors as linguistic and rhetorical models of the educational discourse community.

As education students see their professors as linguistic and literacy experts in their field, professors are primed to become language role models for their students. Based on this fact, education students differ from other undergraduates in their need to develop and demonstrate a high level of literacy ability (Gambell, 1991; Tschannen-Moran, Woolfolk Hoy, \& Hoy, 1998). This is recognized by teacher certification exams that measure not only teaching pedagogy, but also communicative and literacy skills. Not only do teachers serve as writing and reading role models, they are also charged with the task of teaching students how to read and write. This process requires that teachers be self-reflective as readers and writers. Further, their self-perceptions of writing are critically important. If teachers can be self-reflective regarding their own practices, they may better understand their students' writing and help propel students' advancement towards proficiency (Gambell, 1991).

\section{Writing as Part of Certification Requirements}

As part of their teacher preparation and to acquire New York State licensure, students in the present study needed to complete and pass a portfolio-based project, edTPA. The edTPA is a rigorous, comprehensive written assessment of teachers' knowledge and skills, which are deemed necessary to teach all children (edTPA, 2016). Teachers were also required to pass the Academic Literacy Skills Test (ALST), which measured reading and analytical writing skills. Notably, after the completion of the current study, the Board of Regents eliminated the ALST as a requirement for New York State teachers. This literacy exam contained multiple-choice questions, two short essays, and a focused essay. This criterion referenced exam measured prospective teachers' own English reading and writing skills (Program Overview, n.d.). In other words, it did not measure their ability to teach reading and writing; instead, it measured these skills in the prospective teachers. Currently, the Board of Regents is piloting a new subtest to assess teacher candidates' reading and writing skills, which will become part of the Educating All Students (EAS) certification exam.

As part of the teacher certification process for the edTPA (and in the past for the ALST) provisions exist for students who do not pass these assessments. Courses that contain the same rigorous standards as the edTPA, and in the past for the ALST, serve as a safety net. That is, if a student received a grade of $B$ or higher in these safety-net courses, they could obtain licensure to teach even if they have not passed the edTPA or ALST. The course in which students were 
enrolled in this study was a safety-net course specific to the ALST; in this regard, it possessed the rigor and real-world skills in literacy necessary to demonstrate eligibility for licensure (Halliday et al., 2015) and to prepare students for the Content Specialty Test: Multi-Subject Early Childhood Literacy Exam.

Historically, many standardized tests have been scrutinized as possessing a bias against certain racial groups. In 2015, a federal judge ruled that two previous teacher certification exams were discriminatory, but determined that the ALST was not biased (Taylor, 2017). The ALST was labeled as necessary because it measured skills essential for the teaching profession. However, in 2017, the ALST was eliminated because it was continuously difficult for minority, specifically black and Hispanic, teacher candidates to pass (Taylor, 2017). Nevertheless, the literacy skills assessed in the exam are important for teacher candidates to possess in order to become effective teachers. Proponents of ALST's elimination argue that the test is not necessary given that candidates' bachelor's degree completion inherently equates with the necessary and requisite literacy and communication skills needed for the profession. However, this assertion warrants investigation.

\section{Overview of Present Study}

The current study examined the performance of students in one particular disciplineteacher education. It sought to understand the preparedness, with regards to literacy ability, of preservice early childhood education students who initially started their higher education journey at a 2-year community college versus a 4-year college. Given the current and projected teacher shortage and the need for diversity among teachers, (Dee \& Goldhaber, 2017; Dubin, 2017), it is important to understand the skills and needs of preservice teachers who start at community colleges. As stated above, community college students are typically from diverse populations (American Association of Community Colleges, 2016; Dougherty \& Townsend, 2006); therefore, they have the potential to address the teacher shortage with regards to the need for diversity. If education students from community colleges are well prepared, they should perform on par with education students who have attended a 4-year college from freshman year onward.

In addition, the majority of studies have focused on remedial services for underprepared students; however, questions remain about the types and effectiveness of supports available to students who transfer to 4-year universities from community colleges. It remains to be examined how students experience the transition, as well as how community college coursework aligns with the work expected at 4-year institutions.

As an initial area of investigation, this study focused on students' writing skills, final grades, and responses to surveys in two sections of one course within a teacher education program. This paper addresses the following research hypotheses:

- There will be no difference between writing scores and end-of-year semester grades of students who start at a 2-year community college as compared to students who start at a 4-year college in a rigorous course that serves as a safety net for a teacher certification exam.

- There will be no difference in literacy supports that community college students seek as compared to students who start at a 4-year college.

- There will be no difference in college experience based on point of entry: 2-year community college or 4-year college.

- There will be no difference in how identity as a writer emerges and changes based on point of entry: community college start versus 4-year college start. 
- There will be no difference in help-seeking behaviors for written work based on point of entry: community college versus 4-year start.

\section{Methods}

\section{Participants}

Twenty-nine early childhood students, enrolled in two sections of the same literacy development and teaching course during the fall of 2015 and the spring of 2016, participated in this study. This course was offered by a 4-year college located in a large metropolitan area in the northeastern United States. All participants were female, which is common in early childhood courses. Because this study was conducted as part of the typical educational experience of college students, demographic data was not collected; however, participants seemed to represent a similar cross section of the overall diversity of the university. The ethnic breakdown of the university was $25.35 \%$ White, 19.51\% Hispanic, $17.72 \%$ Black or African American, 16\% Asian, $19.55 \%$ Missing/Other, $1.46 \%$, two or more races, $0.26 \%$ American Indian or Alaskan Native, and $0.17 \%$ Native Hawaiian or Other Pacific Islander. Information on student GPA was available and that data was subject to analysis by a t-test (see Results section). The key characteristic examined was point of admission to college: 2-year community college or 4-year institution. Seventeen participants started at community colleges and then transferred to the college where this study took place, and 12 participants started at 4-year institutions.

IRB approval was obtained to conduct a secondary data analysis. To clarify, all of the measures were embedded into the sessions as part of the regular curriculum in the course. It was an undergraduate literacy teaching and instruction course so the surveys were relevant to supporting students in reflecting on their own writing practice and support system. The categorization of the study as a secondary data analysis meant no consent forms were required, but all data was de-identified for the analysis.

At the 4-year college in this study, all students had access to the Learning Center where they could work one-on-one with writing tutors. These tutors focused their feedback on grammar and syntax rather than on the content of papers. Tutors are available by appointment or on a drop-in basis and the center is open every day of the week. Students in the Teacher Education program also had access to an in-house writing tutor who focused on grammar, syntactical structure, and content of writing papers. The Education department had one tutor for approximately 2,514 students. The tutor was available three times a week for three-hour intervals. Students could attend the tutoring sessions on a drop-in format.

For transfer students in particular, there are two main forms of support. The first is the Transfer Student Services Center, which functions to assemble students' transfer credits. Thus, its role is logistical. The second is a peer-mentoring program called Transfer Nation. This is a mentorship program to which transfer students can apply through the Transfer Student Services Center. This peer-mentoring program connects students with resources on campus, such as the Learning Center and the Career Center. In order for transfer students to benefit from this service, they must seek it out and apply for it. They are not automatically enrolled. It is likely that many campuses offer slightly different services for their general student population, remedial students, and transfer students. 


\section{Materials and Procedures}

The course taken by all research participants focused on the theory and practice of early childhood literacy development and included several assessments that require high-level reading and writing skills. Students were required to critically read and synthesize two to three articles each week. Additionally, students engaged in weekly on-the-spot, in-class writing assignments during which students composed high-quality written paragraphs in response to a question based on the readings for the week. Students also wrote a research-based final term paper, among other assessments.

Preliminary survey. At the start of each semester, participants completed a researcherdeveloped survey, the College Experience Survey (see Appendix A.). This survey assessed two factors: students' experiences of college and students' self-efficacy regarding reading and writing. There were seven items addressing each factor. The survey was developed using researchbased models (Tschannen-Moran, Woolfolk Hoy, \& Hoy, 1998). It was field tested with students in a previous semester. Experts in the field also reviewed it to provide evidence of content validity for the factors and for the entire survey. Use of researcher-developed surveys is consistent with the work of other researchers in the education field (Abdel-Maksoud, 2018; Hussien, 2018; Victor, 2017). The purpose of the survey was to allow the professor to get to know the students better in regard to their experience thus far in academia and their perception of themselves as readers and writers. Participants responded to 5-point Likert scale items. Students had 10 minutes to complete this survey. Survey data from the spring semester was collected for the purpose of this study.

In-class written response. During the course of the semester, students were assigned readings for each weekly class session. The readings included articles from peer-reviewed journals, book chapters from research books or textbooks, and articles from high-level magazines or newspapers. Typically, two readings were assigned each week. The readings were rigorous and required close reading of the text. Students were encouraged to annotate hard copies of the text and take notes while they read.

Each class session began with an in-class written response to the readings. The professor posted the question on the overhead at the start of class and students were given anywhere from 5-15 minutes to respond based on the complexity of the question and on student engagement in writing. The students responded to the question from memory; the articles were not available to reference.

The questions tapped students' ability to extract the main argument or purpose of the text. For example, in response to a book chapter on the brain's ability to acquire literacy skills, the question was: "Biologically speaking, what is the difference between the ability to see and talk vs. the ability to read?" In response to an article from a peer-reviewed journal, the question asked students to explain the steps of the method the authors put forth to determine what vocabulary words should be chosen from a text being used with young children.

Students wrote using paper and pen/pencil and the professor collected the responses at the end of the time, when most students seemed to have completed their writing. Then, the question was discussed as a whole group and students shared their response from memory. The responses were scored on a $0-3$ scale $(0=$ non-response, late, absent; $1=$ attempted to answer the question, but missed the point of the article; 2 = demonstrated a general understanding of the question, but lacked specifics or included extraneous/distracting language; $3=$ demonstrated a strong understanding of the question by including examples and reasoning from the text/ response includes details from the text to thoroughly explain the answer). 
Research papers. Research papers were submitted at the end of the semester, one week before the final exam. The research papers required students to explain the five components of literacy and four components of balanced literacy. Three questions, what each component is, why it is important, and how it should be taught, needed to be answered in one to two paragraphs with citations. The students were instructed to use the readings for each week of the semester as their sources. A detailed outline and rubric was provided for the assignment. To achieve consistency with scoring using the rubric, two researchers jointly scored a random sample of $20 \%$ of the papers. When agreement in scoring reached $98 \%$, the instructor used the agreed upon criteria of the rubric to score the remaining papers.

Final grades. At the conclusion of the semester, final grades were calculated based on performance on five assignments. Each of the five assignments accounted for $20 \%$ of the final grade. In addition to the in-class written responses and the research paper explained above, the final grade was also comprised of three Linked Literacy Lesson Organizer (LLLO) assignments, a detailed lesson plan project, and a final exam.

The LLLO projects included a series of three progressively more difficult lesson planning sequences, which required students to develop literacy lesson plans based on a specific standard or group of standards. Alignment between the standard, objective, activity, and assessment of each lesson in the sequence was evaluated along with students' ability to create developmentally appropriate, engaging, and high-quality literacy lessons. Templates for each of the three LLLO assignments were provided to the students, along with a detailed rubric. The professor went over the expectations for the assignment a week before each of the three LLLOs was due.

A detailed, interactive, read-aloud lesson plan, with an analysis of student work and a reflection paper based on conducting the lesson, was completed mid-way through the semester. A template that explained each of the components of the lesson plan was provided to the students. The teacher modeled the use of the detailed lesson plan in a 2-hour fieldwork session conducted in addition to the class session that week.

The final exam was comprised of 47 multiple-choice questions and one essay question. One-week prior to the exam, a detailed study guide was provided to the students. They were given two hours to complete the final exam during the college-scheduled time during final exam week.

End of Semester Survey (EoS survey). On the last day of the spring semester, students completed a questionnaire about their college experience. Students in the fall semester did not complete this survey. There were two versions of the EoS survey, one for those who started at 4year colleges and one for those who started at community colleges (see Appendixex B \& C). Both surveys contained 13 open-ended questions. The EoS survey focused on students' experiences during their first 2 years of college and then their second 2 years. In general, the questions were about writing, support that students received to improve their writing, and their understanding of themselves as writers. There were also four questions about college life in general. The difference between the two versions of the survey had to do with wording such as, "In your first 2 years of college..." for 4-year start students, and "At your previous school..." for community-college transfer students. Students had 15 minutes to complete the surveys.

After the surveys were collected, emergent coding was used to uncover common themes and categories in the responses. Following the protocol used by Eddy and VanDerLinden (2006), the responses were reviewed several times and categories/themes were established collaboratively by two researchers. Inter-rater reliability was assessed for four surveys and there 
was $98 \%$ agreement. Discrepancies were ameliorated through discussion. Then the remaining surveys were coded based on the protocol achieved during discussion. The surveys were used to create a narrative of student experience based on point of admission.

\section{Data Analysis}

Differences between 2-year and 4-year start students were analyzed on their in-class writing responses, research paper, and final grade. Also, differences between 2- and 4-year start students were investigated on the college experience surveys and the open-ended questionnaire.

\section{Results}

\section{Quantitative Analyses}

A power analysis was conducted using $\mathrm{G}^{*}$ Power (Faul, Erdfelder, Lang, \& Buchner, 2007). The results indicated that there was $70 \%$ power to detect an effect of 0.8 with a total sample size approximate to that of the current study ( $\mathrm{G}^{*}$ Power recommended 16 participants per group for a total of 32, and the current study had groups of 17 and 12 participants for a total of 39).

Grade point average was used to determine the comparability of the two groups in terms of academic performance. Results of independent samples t-tests, $t(27)=-1.34, p=.19$, demonstrated that no significant difference existed between the GPA of 2-year start $(M=3.35$, $\mathrm{SD}=.36)$ and 4-year start $(\mathrm{M}=3.52, \mathrm{SD}=.26)$ students. Therefore, GPA was not used as a covariate in the subsequent analyses.

The extent to which the assessment tools were related was analyzed using a Pearson product-moment correlation. Results (see Table 1) showed that the degree of the relationship between the final grade in the class was, as expected, strongly and significantly related with inclass writing $(r=.82, p<.000)$ and research paper $(r=.67, p<.000)$. However, the relationship between in-class writing and research paper was not significantly related and only showed a weak to moderate relationship $(r=.34, p=.07)$. While these were both writing assignments, the nature of the tasks seemed to tap different skills.

Table 1. Correlations Between Final Grade, In-Class Writing, Research Paper

\begin{tabular}{|c|c|c|c|}
\hline & Final Grade & In-Class Writing & Research Paper \\
\hline Final Grade & & $.82^{\star \star *}$ & $.67^{\star \star \star}$ \\
\hline In-Class Writing & & & .34 \\
\hline \multicolumn{4}{|l|}{ Research Paper } \\
\hline Note. ${ }^{* * *} \mathrm{p}<.000$ & & & \\
\hline
\end{tabular}

Three independent samples t-tests were conducted to investigate differences in performance on in-class writing, research paper, and final grade in the class between students admitted originally to 2-year or 4-year institutions. Results of all three t-tests were non-significant (in-class writing: $\mathrm{t}(27)=-1.11, \mathrm{p}=.28$; research paper: $\mathrm{t}(27)=-.63, \mathrm{p}=.54$; final grade: $\mathrm{t}(27)=$ $-1.47, p=.15$ ) indicating that the 2-year start and 4-year start students did not differ in their performance on these writing assignments or in their overall grade in the course. 
Two independent samples t-tests were conducted to investigate differences in responses on the College Experience Survey between students admitted originally to 2-year or 4-year institutions. A composite score was created for the two intended variables from the survey: college experience and identity as a reader/writer. Each variable was comprised of seven 5-point Likert scale questions. Results of the two t-tests were non-significant (college experience: $\mathrm{t}(10)=-.11$, $\mathrm{p}=.91$; identity as a reader/writer $\mathrm{t}(10)=.57, \mathrm{p}=.58$ ) indicating that the 2 - and 4-year students did not differ in their perceived experience as college students or in their perceptions of themselves as college-level readers and writers.

\section{Qualitative Analyses}

The qualitative data supports the quantitative data in that community college students viewed themselves as capable and are able to succeed upon transfer. This qualitative data also point to the stressors that come with transfer and the need for personalized support. Below are results that emerged from responses to the End-of-Semester surveys (EoS; also see Table 2).

Table 1. Summary of Responses to End of Semester (EoS) Survey. Percentage of Respondents by Category

\begin{tabular}{|c|c|c|}
\hline Item/Category & Four-Year Start & $\begin{array}{l}\text { Community } \\
\text { College Start }\end{array}$ \\
\hline Positive first 2 years & $42 \%$ & $35 \%$ \\
\hline Negative first 2 years & 8 & 6 \\
\hline \multicolumn{3}{|l|}{ During first 2 years: } \\
\hline Variety of writing assignments & 50 & 29 \\
\hline No help with writing & 25 & 6 \\
\hline Help with writing & 25 & 35 \\
\hline Peer help & 0 & 12 \\
\hline Writing/learning center & 8 & 12 \\
\hline Book/style manual & 17 & 0 \\
\hline Drafts with prof. feedback & 8 & 12 \\
\hline Positive identity as a writer & 33 & 24 \\
\hline Help from advisors & 0 & 0 \\
\hline Advisors not helpful & 0 & 6 \\
\hline Transfer smooth & 17 & 6 \\
\hline Transfer challenging & 25 & 29 \\
\hline Positive second 2 years & 17 & 6 \\
\hline Negative second 2 years & 25 & 18 \\
\hline \multicolumn{3}{|l|}{ During second 2 years: } \\
\hline Variety of writing assignments & 8 & \\
\hline No help with writing & 8 & 6 \\
\hline Help with writing & 50 & 35 \\
\hline Peer help & 33 & 3 \\
\hline Writing/learning center & 25 & 12 \\
\hline
\end{tabular}




\begin{tabular}{lcc}
\hline Book/style manual & 8 & 0 \\
\hline Drafts with prof. feedback & 8 & 6 \\
\hline Positive Identity as a writer & 25 & 24 \\
Growth as a writer & 25 & 18 \\
No growth as a writer & 8 & 18 \\
\hline Decreased growth as writer & 17 & 6 \\
\hline Help from advisors & 8 & 0 \\
\hline Advisors not helpful & 33 & 24 \\
\hline
\end{tabular}

A positive first 2 years of college experience was reported by a larger percentage of students who started at 4-year colleges as compared to students who started at community colleges; the percentages were 42 and 35 respectively. This is a relatively small difference and may be negated by the percentages of students who reported a negative first 2 years of experience. The fact that community college students received more help with writing than 4-year starts is pertinent to this study. The help may be what enabled them to succeed and view themselves as competent.

During their first 2 years, 2-year starts reported receiving more help with writing, which included peer help, feedback from professors on draft assignments, and support from the writing center. Four-year starts did report some help with writing, such as using books and style manuals. Only one 4-year start reported receiving personal help, and that was feedback from a professor. One 2-year start noted, "They give [sic] me a lot of help for my English. They give me a tutor for reading and writing." In response to another prompt, this same student added "I got my own tutor for a specific time and I don't have to wait. And she know [sic] my mistakes or where was my weakness." Another 2-year start emphasized that writing help during her first two years consisted of "the tutors and their flexibility in sessions." A 4-year start responded that, "the quiet of the library helped her to concentrate and complete her papers." Another 4-year start noted that "professor guidance and online resources" helped her with writing. A third 4-year start did not know that there was a writing center on campus.

Several 4-year starts stated that the writing center did not have convenient hours and that there were not enough tutors: "Due to the schedule of the center, I am not able to attend;" "You have to make an appointment and you still have to wait." This inconvenience made it impossible for some 4-year starts to use the writing center. These 4-year starts reported using style manuals and books to help them with their writing, responding: "A writers reference," "A book I had to purchase for English 101, which had a lot of tips for writing helped me the most." While some 4year starts did note personal help, 2-year starts wrote in more detail and gave more specific examples such as: "The professors were easy to contact and the students were a big help." "They helped me with editing, I got feedback about my grammar and writing style." In terms of their identity as writers, the same number of 2- and 4-year starts reported having a positive identity.

The transition from the first 2 years to the second 2 years was smooth for those students who started at the 4-year college where this study was conducted. One student who transferred from a community college to this college reported a smooth transfer. Five 2-year starts reported transfer as being challenging. For example, some classes taken at the 2-year college were not accepted so students lost credits; it was difficult to find classes that were needed and available; advisors were not helpful. Students reported being given conflicting information and needing to go to many different offices for advisement, registration, transcript analysis, and financial aid. 
Three students who transferred to this college from another 4-year college also experienced similar challenges with transfer.

During the second 2 years, one 4-year start from this institution reported a positive experience. Two transfer students also reported positive second 2-year experiences; one respondent transferred from another 4-year college; and the other respondent was from a 2-year college. Six transfer students, three from 2-year and three from other 4-year colleges reported negative experiences overall during their second 2 years of college.

Three 4-year starts and four 2-year starts reported a positive identity as a writer during the second 2 years of college. However, seven transfer students reported no growth or decreased growth in regards to their identity as a writer during their second 2 years of college. This may reflect the increased difficulty of writing assignments as noted by some students. Four-year starts did report more help with writing during their second 2 years as compared to the first 2 years, but this help was mostly from peers. Two-year starts reported the same amount of help with writing during all 4 years, but the change was less support from the writing center and more support from peers during the second 2 years. The support of a community of practice may have influenced their positive identity (Wenger, 1998).

In addition to the summary above, there were many other responses to the EoS survey. These responses are summarized in Table 2. Not all participants responded to all prompts; therefore, responses are reported as percentages.

\section{Discussion}

The purpose of the current study was to begin an investigation of the preparedness of students who started their college career at a community college and are now teacher candidates at a 4-year college. There are many facets to examining preparedness; the scope of this study focused on a snapshot of teacher education students, their literacy skills, and their ability in one particular education class. While there are many other areas deserving of study, the research reported here is focused on this one area.

To measure whether or not community college students were adequately prepared for writing tasks, results of in-class writing and grades on a research paper were compared to students who began their studies at a 4-year college. In addition, final grades in the course were analyzed as a factor of college starting point. Students who started at a 4-year college were used as a benchmark of comparison for preparedness.

Results of independent t-tests revealed no significant differences between students based on point of entry on two writing assignments and final grades. This indicates that students who started at a community college performed as well as students who started at 4-year colleges. Grade point average was also examined to determine the overall academic performance of the two groups. There was no significant difference between 2-year starts and 4-year starts on GPA. While this was examined to ascertain the need for a covariate, the fact that groups were equal in this measure also confirms the preparedness of 2-year start students as compared to 4-year start college students.

While community college students may have needed remedial courses and other supports to advance to senior college, once they transferred to senior college, they were able to demonstrate the ability to succeed as well as the 4-year start students. Because community college students in this study are able to perform well, it is important that college educators 
recognize the value of community college students as part of 4-year institutions. In this particular study, it is important to note that community college students deserve a place in teacher education programs so that they can become teachers, addressing both the teacher shortage and lack of diversity of teachers in the United States.

Results of qualitative data support the quantitative data. While both 2-year and 4-year starts had a positive identity as writers and positive experiences during their first 2 years of college, the personal support that 2-year starts had may have enabled them to succeed and continue to have a positive identity as writers. If community college students enter college with less than adequate literacy skills, the support of peers, tutors, writing centers, and professors provides them with the skills needed for senior college.

Two-year start students have the ability to succeed at 4-year colleges. At a time when 4year institutions may be experiencing decreased enrollment, recruitment of 2-year students has the potential to address that decrease. Qualitative data also revealed that transfer was challenging for many 2-year start students. Policies and procedures that enable smooth transfer such as knowledgeable advisors, streamlined advisement, articulation agreements, jointly enrolled programs, and flexible class schedules may promote easier access and more positive experiences for not only 2-year start transfer students, but also transfer students from other 4year colleges. In support of our findings, a recent article from Inside Higher Ed (Lederman, 2017) stated the 4-year colleges continue to create unnecessary hurdles for a large portion of their customers, transfer students. Four-year institutions should consider an advisement process that uses the framework of Relational Advising, which has been demonstrated to be helpful to all students (Snyder-Duch \& Schwartz, 2017). Additional support services, such as more tutors and more accessible hours for writing centers, would also be beneficial.

It should be noted that although community college and junior colleges are a part of the educational landscape in other countries, the function of these institutions may vary. An article by Matthew Dembicki (2015) for the Community College Times explained that in the last few years, representatives of the American Association of Community Colleges have travelled internationally to help several countries (e.g., Colombia, Mexico, Brazil, and Indonesia) learn more and adopt the 2-year college model. Colombia and Mexico are examples of two countries that have a traditional university educational system and a separate technical/vocational college system.

As a number of countries begin to consider and implement community college models that give more students access to education and a pathway to 4-year institutions, the findings of the current study are important to consider. These findings show that supports, such as tutoring and writing centers, make a difference in student achievement. Additionally, educational pedagogy that goes beyond domain-specific skills to teach critical thinking, reasoning skills, and analytical writing ability arm students with generalizable skills that can be used in subsequent courses at universities and in various professional settings. Lastly, students' attitudes and self-efficacy make a large difference in student achievement and resiliency. Thus, supports for students should also focus on self-regulations skills.

Further research is needed to examine the skills of community college students in other geographic areas and in other academic disciplines. A limitation of this study was the lack of demographic data and the use of self-reports. Another limitation is the lack of academic information on the 2-year start students' preparedness. However, as this study argues, when these students get to the 4-year college they should be seen as academically equal. Also, more rigorous forms of writing proficiency should be considered in follow-up studies. Finally, the current 
study was limited in its power to determine smaller differences that may have been present. Future studies should examine these questions with a larger sample size.

This was a preliminary study that focused on a narrow, but important, subsection of the transfer student population in the United States, transfer students in the field of education. In a field desperate for strong, diverse teacher candidates, any and all barriers, including stereotypes about students' academic ability, should be removed in an effort to provide equal opportunity for all.

\section{References}

Abdel-Maksoud, N. F. (2018). The relationship between students' satisfaction in the LMS "Acadox" and their perceptions of its usefulness, and ease of use. Journal of Education and Learning, (7)2, 184190. Retrieved from https://eric.ed.gov/contentdelivery/servlet/ERICServlet?accno=EJ1167070

Adelman, C. (1998). The kiss of death? An alternative view of college remediation. National CrossTalk, 6(3), 11.

Association of Community Colleges, (2010). Historical information. Retrieved from http://www2.aacc.nche.edu/research/index students.htm0

Bailey, T. \& Cho, S. (2010). Issue brief: Developmental education in community colleges, prepared for The White House Summit on Community College. Community College Research Center, Teachers College, Columbia University. Retrieved from http://www2.ed.gov/PDFDocs/college-completion/07developmental-education-in-community-colleges.pdf

BMCC Factbook (2009). BMCC Factbook 2008-2009. Retrieved from http://www.bmcc.cuny.edu/iresearch/upload/FB20082009.pdf

Bettinger, E., \& Long, B. T. (2004). Shape up or ship out: The effects of remediation on students at fouryear colleges (Working Paper No. 10369). Cambridge, MA: National Bureau of Economic Research.

Bettinger, E., \& Long, B. T. (2005). Remediation at the community college: Student participation and outcomes. New Directions for Community Colleges, 129, 17-26.

Callahan, N., \& Chumney, D. (2009). "Write like college:" How remedial writing courses at a community college and a research university position "at-risk" students in the field of higher education. Teachers College Record, 111(7), 1619-1664.

Dee, T. S., \& Goldhaber, D. (2017). Understanding and addressing teacher shortages in the United States. The Brookings Institution, Hamilton Project, Policy Proposal 2017-05. Retrieved from https://www.brookings.edu/wpcontent/uploads/2017/04/es 20170426 understanding and addressing teacher shortages in u s pp dee goldhaber.pdf

Dembicki, M. (2015, April 15). Growing interest in community colleges spreads internationally. Study USA. Retrieved from https://www.studyusa.com/en/a/347/growing-interest-in-community-collegesspreads-internationally

Dougherty, K. J. \& Townsend, B. K. (2006). Community college mission: A theoretical and historical perspective. In B. K. Townsend \& K. J. Dougherty (Eds.), Community college missions in the 21st century (pp. 5 -14). San Francisco: Jossey-Bass. 
Doyle, W. R. (2009). Impact of increased academic intensity on transfer rates: An application of matching estimators to student-unit record data. Research in Higher Education, 50, 52-72.

Dubin, J. (2017). Investing wisely in teacher preparation. American Educator, 41(3), 31-36.

edTPA, (2016). About edTPA overview. Retrieved from http://edtpa.aacte.org/about-edtpa\#Overview-0

Eddy, P. L., \& VanDerLinden, K. E., (2006). Emerging definition of leadership in higher education: New visions of leadership or same old "hero" leader? Community College Review, 34(1), 5-26.

Faul, F., Erdfelder, E., Lang, A.-G., \& Buchner, A. (2007). G*Power 3: A flexible statistical power analysis program for the social, behavioral, and biomedical sciences. Behavior Research Methods, 39, 175-191.

Gambell, Trevor J. (1991). University education students' self-perceptions of writing. Canadian Journal of Education, 16(4), 420-33.

Halliday, W., Dance, B., Davis, E., Fagerheim, B. Hedrich, A., Lundstrom, K., \& Martin, P. (2015). An information literacy snapshot: Authentic assessment across the curriculum. College and Research Libraries, 76(2), 170-187.

Harris, E. (2017, March 19). CUNY to revamp remedial programs, hoping to lift graduation rates. The New York Times. Retrieved from https://www.nytimes.com/2017/03/19/nyregion/cuny-remedialprograms.html

Hussien, A. M. (2018). Culture of traits in Arabic language education: Students' perception of the communicative traits model. International Journal of Instruction, (11)4, 467-484.

James, J. (2012). The college wage premium. Economic Commentary. (2012)10/11, 1-4.

Kayapinar, U. (2014) Measuring essay assessment: Intra-rater and inter-rater reliability. Eurasian Journal of Educational Research, 57, 13-136.

Kopko, E., \& Crosta, P. (2016). Should community college students earn an associate degree before transferring to a 4-year institution? Research in Higher Education, 57(2), 190-222. doi: $10.1007 / \mathrm{s} 11162-015-9383-x$

Lederman, D. (2017, September 14). The Bermuda triangle of credit transfer. Inside Higher Ed. Retrieved from https://www.insidehighered.com.

Oreopoulos, P. \& Petronijevic, U., (2013). Making college worth it: A review of the returns to higher education. Future of Children, 41-65.

Pajarares, F. (2003). Self-efficacy beliefs, motivation, and achievement in writing: A review of the literature. Reading and Writing Quarterly: Overcoming Learning Difficulties, 19(2), 139-158.

Peralta, K. (2014, June). Benefits of college still outweigh costs, fed study says. US News. Retrieved from https://www.usnews.com/news/articles/2014/06/24/benefits-of-college-still-outweigh-costs-fedstudy-says

Perin, D. (2013). Literacy skills among academically underprepared students. Community College Review, $4(2), 118-136$.

Perin, D. (2012). Teaching academically underprepared students. In J. Levin and S. Kater (Eds.), Understanding community colleges (pp. 87-103). Core Concepts in Higher Education. New York, NY: Routledge. 
Perin, D., Bork, R. H., Peverly, S. T., Mason, L. H., \& Vaselewski, M. (2011). A contextualized intervention for community college developmental reading and writing students. CCRC Working Paper No. 38. Community College Research Center, Columbia University.

Perin, D., \& Charron, K. (2006). Lights just click on every day. In T. Bailey \& Morest, V. S. (Eds.), Defending the community college equity agenda (pp. 155-194). Baltimore, MD: The Johns Hopkins University Press.

Perin, D. (2002). Summary of themes and issues. 2001-2002. Seminar series. New roles of community colleges. Community College Research Center, Columbia University. Retrieved from http://ccrc.tc.columbia.edu/Community-College-History-Mission-and-Challenges.html?all=1

Perin, D., Keselman, A., \& Monopoli, M. (2003). The academic writing of community college remedial students: Text and learner variables. Higher Education, 45(1), 19-42.

Powers, D. E., Fowles, M. E., \& Welsh, C. K. (2001). Relating performance on a standardized assessment to performance on selected academic writing activities. Educational Assessment, 7(3), 227-253.

Program Overview. (nd). ALST program overview. Retrieved from http://nystce.nesinc.com/NY17 overview.asp

Schunk, D., \& Zimmerman, B. (Eds.) (1998). Self-regulated learning: From teaching to self-reflective practice. New York: Guilford Press.

Shannon, H. D., \& Smith, R. C. (2006). A case for the community college's open access admission. In B. K. Townsend \& K. J. Dougherty (Eds.). Community college missions in the 21st century (pp. 1521). San Francisco: Jossey-Bass.

Snyder-Duch, J. \& Schwartz, H. L. (2017). Relational advising. NEA Higher Education Advocate, (35)4, 811.

Taylor, K. (2017, March 13). Regents drop teacher literacy test seen as discriminatory. The New York Times. Retrieved from https://www.nytimes.com/2017/03/13/nyregion/ny-regents-teacher-examsalst.html? $\quad r=0$

Tschannen-Moran, M., Woolfolk Hoy, A., \& Hoy, W.K. (1998). Teacher efficacy: Its meaning and measure. Review of Educational Research. 68(2), 202-248.

Victor, A. A. (2017). Analysis of principals' managerial competencies for effective management of school resources in secondary schools in Anambra State, Nigeria. International Journal of Social Sciences, Humanities and Education, (1)4, 236-245.

Wenger, E. (1998). Communities of practice: Learning meaning and identity. Cambridge, UK: Cambridge University Press.

Williams, J. D., \& Takaku, S. (2011). Help seeking, self-efficacy, and writing performance among college students. Journal of Writing Research, 3(1), 1-18. 


\section{Appendixes}

\section{Appendix A. Preliminary Survey/College Experience Survey}

As we work together this semester, it helps me to know the prior experience of the class. I use this information as I am planning activities and in class support. This information does not affect your grade. Please circle the number that corresponds to each statement below:

1 = strongly disagree, 5 = strongly agree

A. When I entered college as a freshman, I received a lot of support with written assignments. strongly disagree

2

\section{3}

3
4 strongly agree

B. When I entered college as a freshman, I felt very confident in my ability to complete written assignments.
12
23
34
5

strongly disagree

C. The college registration process has been easy for me.

1

2 strongly disagree

4 strongly agree

D. During my first 2 years of college, professors offered assistance with written assignments.

strongly agree

5

5

strongly agree

E. When I started college, I was able to complete written assignments easily. strongly disagree

2

2 strongly disagree
3
4
5

strongly agree

F. When I am given written assignments, it is easy for me to complete those assignments. strongly disagree

2

3
4 4

5 strongly agree

G. When I started college, I understood how rubrics were used in grading written assignments.

$\begin{array}{llllll}1 & 2 & 3 & 4 & 5 & \\ \text { strongly disagree } & & & & \text { strongly agree }\end{array}$

$\mathrm{H}$. I have been comfortable with peer review since I started college.
1
2
strongly disagree
3
4
5
strongly agree

I. I spend 4 hours each week reading outside of class.

strongly disagree

23

J. Professors have been using rubrics to grade written assig

1 strongly disagree
23

34

45

strongly agree

K. Peer review has been part of my experience since I was a freshman. 


$\begin{array}{cllll}1 & 2 & 3 & 4 & 5 \\ \text { strongly disagree } & & & & \text { strongly agree }\end{array}$

L. The transition from my first 2 years to my second 2 years at college was easy. strongly disagree

2

M. I am a confident writer. strongly disagree 23

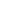

3

5

strongly agree

5

strongly agree

$\mathrm{N}$. There is not much difference between the first 2 years and the second 2 years of college in terms of workload.

1

strongly disagree
$2 \quad 3$

4
5

strongly agree

\section{Appendix B. End of Semester (EoS) Survey-Two-Year Start Students}

Thank you for your answers to these questions. Your answers will help me as I plan for your course and as I continue my work with other students. Your answers do not affect your grade. Your reflection may help you understand the writing process. I may use this information as part of a published paper but your identity will not be known to anyone but me.

1. When you think of your experience at your previous school, what words come to mind?

2. What kinds of writing assignments did you do in your previous school?

3. What helped you as you completed these writing assignments in your previous school?

4. What were some of the challenges of writing during your time at your previous school?

5. What was your identity as a writer in your previous school?

6. How would you describe your identity as a writer now?

7. Please describe the transfer process from your previous school to XXXX college.

8. Please describe your experiences with written assignments here at XXXX college.

9. If you need help with written assignments here at XXXX College, how do you get the help you need?

10. If you need help with other issues here at XXXX college, what are those issues and how do you get that help?

11. Please describe any other aspects of your college life, before and while at XXXX, that you feel help you succeed.

12. Please describe any other aspects of your college life, before and while at XXXX, that you feel hinder your progress.

13. Is there anything else that you would like to share about your college experiences?

\section{Appendix C. End of Semester (EoS) Survey-Four-Year Start Students}

\section{Structured Questionnaire}

Thank you for your answers to these questions. Your answers will help me as I plan for your course and as I continue my work with other students. Your answers do not affect your grade. Your reflection may help you understand the writing process. I may use this information as part of a published paper but your identity will not be known to anyone but me. 
14. When you think of your experience during your first 2 years at $X X X X$ college, what words come to mind?

15. What kinds of writing assignments did you during your first 2 years at $X X X X$ college?

16. What helped you as you completed these writing assignments during your first 2 years at XXXX college?

17. What were some of the challenges of writing during your first 2 years at XXXX college?

18. What was your identity as a writer when you were a freshman/sophomore?

19. How would you describe your identity as a writer now?

20. Please describe the transition process from sophomore to junior year.

21. Please describe your experiences with written assignments during your junior/senior year.

22. If you need help with written assignments as a junior/senior, how do you get the help you need?

23. If you need help with other issues here at XXXX college, what are those issues and how do you get that help?

24. Please describe any other aspects of your college life that you feel help you succeed.

25. Please describe any other aspects of your college life that you feel hinder your progress.

26. Is there anything else that you would like to share about your college experiences? 